\title{
Mechanisms of Increased Susceptibility of Immature and Weaned Pigs to Escherichia coli Heat-Stable Enterotoxin
}

\author{
ADAM G. MEZOFF, NANCY J. JENSEN, AND MITCHELL B. COHEN \\ Division of Gastroenterology and Nutrition, Children's Hospital Research Foundation, and the University of \\ Cincinnati, Cincinnati, Ohio 45229
}

\begin{abstract}
Pigs demonstrate an increased sensitivity and susceptibility to Escherichia coli heat-stable enterotoxin $\left(\mathrm{ST}_{\mathrm{a}}\right)$ in the 1st wk of life and immediately after weaning. To determine the possible mechanisms for this increased susceptibility, we compared $\mathrm{ST}_{\mathrm{a}}$ binding, guanylate cyclase activation, and photoaffinity cross-linking to porcine jejunal brush border membranes prepared from immature ( $\leq 1$ wk of age) versus adult pigs as well as 3 wk-old weaned versus unweaned pigs. The $\mathbf{S T}_{a}$ binding capacity of immature pigs was nearly twice that of adult pigs $\left(11.73 \pm 1.52\right.$ versus $6.00 \pm 0.96 \times 10^{-11} \mathrm{~mol} / \mathrm{L}, p<$ 0.001 ), and the $\mathrm{ST}_{\mathrm{a}}$ binding capacity of weaned pigs was nearly three times greater than that of unweaned pigs $\left(17.48 \pm 2.10\right.$ versus $4.86 \pm 1.02 \times 10^{-11} \mathrm{~mol} / \mathrm{L}, p<$ 0.001). Scatchard analysis suggested a single class of $\mathrm{ST}_{\mathrm{a}}$ receptor, with an association of binding constant of $\sim 10^{9}$ $\mathrm{L} / \mathrm{mol}$ at all ages. Maximum guanylate cyclase response (expressed as pmol cyclic GMP generated/mg brush border membrane protein/min) was greater in immature versus adult pigs $(1312 \pm 831$ versus $320 \pm 92, p<0.02)$. Weaned pigs had a greater maximum guanylate cyclase activation than unweaned pigs $(1126 \pm 692$ versus $624 \pm 298)$; however, this difference was not statistically significant. Autoradiograms demonstrated specific cross-linking of ${ }^{125} \mathrm{I}-\mathrm{ST} \mathrm{T}_{\mathrm{a}}$ to a number of distinct radiolabeled bands $(62,66$, $84,92,160$, and $165 \mathrm{kD})$. There was a difference in the size and trypsin sensitivity of these radiolabeled bands as a function of age and weaning. Treatment with trypsin decreased the intensity of the 160 to $165-\mathrm{kD}$ bands while increasing the intensity of the 62- to 66- and 84- to 92-kD bands. These differences in $\mathbf{S T}_{\mathrm{a}}$ binding, guanylate cyclase activation, and $S T_{a}$ receptor size may increase the susceptibility of pigs during the 1 st wk of life and at weaning to $\mathrm{ST}_{\mathrm{a}}$-mediated diarrheal disease. (Pediatr Res 29: 424-428, 1991)
\end{abstract}

\section{Abbreviations}

$\mathrm{ST}_{\mathrm{a}}$, Escherichia coli heat-stable enterotoxin BBM, brush border membrane $K_{a}$, affinity constant of binding

Received June 12, 1990; accepted December 14, 1990.

Correspondence and reprint requests: Mitchell B. Cohen, M.D., Division of Pediatric Gastroenterology, Children's Hospital Medical Center, 3250 Elland Avenue, Cincinnati, OH 45229-2899.

Supported in part by an American Gastroenterological Association/Glaxo Industry Award and by U.S. Public Health Service Grant DK-1908.

Presented in part at the Society for Pediatric Research meeting in Washington, D.C., May 1989 and published in abstract form (Pediatr Res 25:119A, 1989).
$\mathrm{ST}_{\mathrm{a}}$ are a family of related polypeptides that bind to an intestinal receptor (1), stimulate membrane-bound guanylate cyclase $(2,3)$, and thereby induce intestinal secretion (4). This process has been studied in human and rat intestine, and in both there is an increased density of BBM receptors for $\mathrm{ST}_{\mathrm{a}}$ in the immature intestine $(5,6)$. This coincides with the period of increased susceptibility to $\mathrm{ST}_{\mathrm{a}}$-induced diarrheal disease that occurs in early life in humans $(7,8)$. Escherichia coli that produce $\mathrm{ST}_{\mathrm{a}}$ are also natural pathogens for the pig, causing clinically significant diarrheal disease $(9,10)$. Stevens et al. (11) have described two periods of increased porcine responsiveness to $\mathrm{ST}_{\mathrm{a}}$ : 1) during the 1st wk of life (immature animals) and 2) immediately after weaning. These observations provide a unique window of opportunity to investigate the possible mechanisms for increased susceptibility and host responsiveness to enterotoxigenic E. coli in the pig.

The aim of our studies was to determine if increased $\mathrm{ST}_{\mathrm{a}}$ binding and guanylate cyclase activation correlates with the increased susceptibility to $\mathrm{ST}_{\mathrm{a}}$-mediated diarrheal disease found in immature and weaned pigs. Our hypothesis was that the immature pig has an increased binding capacity for $\mathrm{ST}_{\mathrm{a}}$ and increased $\mathrm{ST}_{\mathrm{a}}$-induced guanylate cyclase activation compared with the adult. Similarly, we hypothesized that the weaned pig has an increased binding capacity for $\mathrm{ST}_{\mathrm{a}}$ and an increased guanylate cyclase activation compared with its unweaned counterpart. As a related aim, we wished to determine if there were differences in the cross-linking pattern of ${ }^{125} \mathrm{I}_{-} \mathrm{ST}_{\mathrm{a}}$ to BBM prepared from pigs of different ages.

\section{MATERIALS AND METHODS}

Porcine intestine. Animals were housed at the Midwest Area National Animal Research Center, Ames, Iowa, and the experimental protocol was approved by the Institutional Animal Care and Use Committee. This facility is accredited by the American Association for Accreditation of Lab Animal Care. Suckling pigs were raised and cared for in the same manner as the control pigs previously reported (12). They were housed with their mothers before weaning, and at weaning were separated from their mothers into different rooms, where they received solid food and water (12). Pigs were considered immature if they were $\leq 1 \mathrm{wk}$ of age, and adult if they were $\geq 6$ mo of age. Several groups of pigs were studied: ages $\leq 1$ wk $(n=8)$, weaned ( 3 wk old, weaned $3 \mathrm{~d}$ previously; $n=5$ ), unweaned ( 3 wk old, unweaned; $n=5$ ), and adult $(n=3)$. For some studies, additional pigs age $14 \mathrm{~d}(n=2)$ and 6 wk $(n=2)$ were used. Their intestines were removed, rinsed with normal saline, and immediately frozen at $-70^{\circ} \mathrm{C}$. All experiments were carried out on intestinal segments taken from the proximal third of pig small bowel.

$S T_{\mathrm{a}} . \mathrm{ST}_{\mathrm{a}}$ was purified from $E$. coli strain $18 \mathrm{D}$ as previously described (13). Pure $\mathrm{ST}_{\mathrm{a}}$ was radioiodinated using a lactoperoxidase method, and 4-tyrosine- ${ }^{-125} \mathrm{I}_{-} \mathrm{ST}_{\mathrm{a}}$ was purified by an HPLC technique (14). 
Chemicals. ${ }^{125} \mathrm{I}$-sodium ( $>350 \mathrm{mCi} / \mathrm{mL}$ ) was obtained from Amersham (Arlington Heights, IL). Enzymatic reagents were obtained from Sigma Chemicals Co. (St. Louis, MO), and all other chemicals were reagent grade.

Protein. All protein determinations were performed using the method of Lowry et al. (15), using a BSA standard.

Jejunal $B B M$. BBM were prepared using a modification of the divalent cation precipitation technique described by Schmitz et al. (16). Intestinal mucosa was scraped from 5 to $10-\mathrm{cm}$ thawed segments of proximal jejunum. The mucosa obtained was homogenized in a $250 \mathrm{mM}$ sucrose $/ 1 \mathrm{mM}$ EDTA/ $1 \mathrm{mM}$ DTT/50 $\mathrm{mM}$ Tris/ $\mathrm{HCl}$ buffer solution ( $\mathrm{pH} 7.3$ ) for $2 \mathrm{~min}$ in a Sorvall Omni Mixer (Dupont Instruments, Wilmington, DE). Calcium chloride, to a final concentration of $10 \mathrm{mM}$, was added to the homogenate, and this mixture was stirred for $20 \mathrm{~min}$ at $4^{\circ} \mathrm{C}$. This suspension was centrifuged at $2000 \times g$ for $10 \mathrm{~min}$, and the pellet containing nuclear fragments and mitochondria was discarded. The supernatant was then centrifuged at $17500 \times g$ (to precipitate BBM), and the resultant pellet was washed in $5 \mathrm{mM}$ Tris buffer, $\mathrm{pH} 7.6$, centrifuged at $17500 \times \mathrm{g}$, and then resuspended in $5 \mathrm{mM}$ Tris buffer, pH 7:6.

Disaccharidase determination. To compare BBM preparations from pigs of different ages and feedings, we first validated the similarity of BBM preparations by determining the enrichment of disaccharidase activity from homogenate to the BBM preparation. All specimens tested had a $15.0 \pm 4.4$-fold increase in disaccharidase activity. All intestinal specimens obtained from animals greater than $5 \mathrm{~d}$ old were assayed for sucrase activity by the method of Dahlqvist (17). Specimens obtained from animals $5 \mathrm{~d}$ of age or less were assayed for lactase activity using the method of Dahlqvist as modified by Koldovsky et al. (18).

$S T_{\mathrm{a}}$ binding. For determination of the $\mathrm{K}_{\mathrm{a}}$ and receptor number, a competitive inhibition of binding format was used as previously described $(1,6)$. Briefly, BBM were incubated with ${ }^{125} \mathrm{I}_{-} \mathrm{ST}_{\mathrm{a}}$ in $12 \times 75 \mathrm{~mm}$ glass tubes. Sodium acetate buffer $(100$ $\mathrm{mM}, \mathrm{pH} 4.8$ ) with $0.15 \%$ BSA was added to each tube to bring the total volume to $1 \mathrm{~mL}$. Tubes were incubated at $37^{\circ} \mathrm{C}$ for $1 \mathrm{~h}$, and the reaction was terminated by rapid suction filtration using a Millipore multichamber sampling manifold (Millipore Corp., Boston, MA) and Whatman GF/B glass fiber filters (Whatman Ltd., Maidstone, England) soaked in $0.3 \%$ poly(ethylene)imine (Eastman Kodak, Rochester, NY). Filters were rinsed twice with $3 \mathrm{~mL}$ of ice cold $50-\mathrm{mM}$ sodium acetate, $\mathrm{pH} 4.8$, and counted in a gamma-scintillation spectrometer (Packard Instrument Co., Downers Grove, IL). These counts represented total counts of ${ }^{125} \mathrm{I}_{-} \mathrm{ST}_{\mathrm{a}}$ bound to its BBM receptor. Aliquots of BBM $(25 \mu \mathrm{g})$ were incubated with $100000 \mathrm{cpm}$ of ${ }^{125} \mathrm{I}_{-} \mathrm{ST}_{\mathrm{a}}(45 \mathrm{pM})$ in the presence of increasing concentrations of native $\mathrm{ST}_{a}(0.025-500$ $\mathrm{nM})$. Specific binding was determined by subtracting total counts bound in the presence of excess $\left(500 \mathrm{nM}\right.$ ) native $\mathrm{ST}_{\mathrm{a}}$ (nonspecific binding). The apparent $\mathrm{K}_{\mathrm{a}}$ and receptor binding capacity were determined using the computer program Ligand as described by Munson and Rodbard (19).

Guanylate cyclase activation. $\mathrm{ST}_{\text {-induced }}$ guanylate cyclase activation was determined using the technique described by Waldman et al. (20). BBM were incubated at $32^{\circ} \mathrm{C}$ with guanosine triphosphate and guanosine triphosphate-regenerating mixture, in the presence and absence of $\mathrm{ST}_{a}$. Cyclic GMP generated was assayed by an RIA technique previously validated (4). $\mathrm{ST}_{\mathrm{a}}$ stimulated guanylate cyclase activation was expressed in pmol cyclic GMP generated/mg BBM protein $/ \mathrm{min}$.

Photoaffinity cross-linking of $S T_{\text {a }}$ to $B B M$. Porcine BBM (100 $\mu \mathrm{g})$ were incubated for $60 \mathrm{~min}$ at $37^{\circ} \mathrm{C}$ in $100 \mathrm{mM}$ sodium acetate buffer (pH 4.8) with $800000 \mathrm{cpm}(360 \mathrm{pM})$ of radiolabeled $\mathrm{ST}_{a}$, in the presence and absence of $2 \mu \mathrm{g}(1 \mu \mathrm{M})$ of native $\mathrm{ST}_{\mathrm{a}}$ in a total reaction mixture of $1 \mathrm{~mL}$. This reaction mixture was microfuged for $10 \mathrm{~min}$ at $4^{\circ} \mathrm{C}$, and the pellet resuspended in 10 $\mathrm{mM}$ sodium phosphate buffer solution ( $\mathrm{pH}$ 7.2). Cross-linking of radiolabeled $\mathrm{ST}_{\mathrm{i}}$, bound to its BBM receptor, was then accomplished using the heterobifunctional photoaffinity cross-linking agent $\mathrm{N}$-hydroxysuccinimidyl-4-azidobenzoate. The mixture was left in the dark on ice for $20 \mathrm{~min}$, then pulsed with an 8-min flash of short-wave UV light. The reaction was then terminated by the addition of $50 \mathrm{mM}$ Tris buffer ( $\mathrm{pH} 7.4$ ). These crosslinked porcine BBM were boiled in 2\% SDS and 5\% 2-mercaptoethanol before analysis by SDS-PAGE using a 5\% stacking gel and $10 \%$ resolving gel $(21)$. Gels were stained with Coomassie blue, dried, and exposed to Kodak XAR-2 film for $72 \mathrm{~h}$ at $-70^{\circ} \mathrm{C}$.

DATA presentation and statistical analysis. Individual points were determined in duplicate in the $\mathrm{ST}_{\mathrm{a}}$ binding experiments and in triplicate in the guanylate cyclase activation experiments. Binding capacity at different ages was compared using the $t$ test. Maximum guanylate cyclase activity was compared at different ages using the nonparametric Wilcoxon rank sum test, due to the significant variability of measurements. Statistical significance was assumed at $p<0.05$. Data were expressed as mean \pm SEM.

\section{RESULTS}

$S T_{\mathrm{a}}$ binding. Specific binding of $100000 \mathrm{cpm}$ of ${ }^{125} \mathrm{IST}_{\mathrm{a}}$ increased in a linear manner when BBM protein concentrations ranging from 5 to $80 \mu \mathrm{g}$ were added to $1 \mathrm{~mL}$ of $100 \mathrm{mM}$ sodium acetate buffer ( $\mathrm{pH} 4.8)$. Specific binding increased linearly with incubation time from $15 \mathrm{~min}$ to $45-60 \mathrm{~min}$, at which time a plateau was reached. Therefore, an incubation time of $60 \mathrm{~min}$ and a protein concentration of $25 \mu \mathrm{g}$ were used in all experiments. Binding of ${ }^{125} \mathrm{I}-\mathrm{ST}_{\mathrm{a}}$ to its intestinal BBM receptor was progressively inhibited, in all specimens tested, by increasing doses of native $\mathrm{ST}_{a}$ (Fig. 1). A Scatchard plot (19) of these competitive inhibition of binding curves revealed a linear plot at all ages, indicating a single species of $\mathrm{ST}_{\text {a }}$ receptor (data not shown). The $\mathrm{K}_{\mathrm{a}}$ was the same in all animals tested (approximately $10^{9} \mathrm{~L} /$ mol); however, as shown in Figure 2, the $\mathrm{ST}_{a}$ binding capacity of porcine BBM was highest during the 1st wk of life and just after weaning. The $\mathrm{ST}_{a}$ binding capacity of immature pigs was twice that of adult pigs $\left(11.73 \pm 1.52\right.$ versus $6.00 \pm 0.96 \times 10^{-11}$ $\mathrm{mol} / \mathrm{L}, p<0.001)$. The $\mathrm{ST}_{\mathrm{a}}$ binding capacity of 3 -wk-old weaned pigs was more than three times the $\mathrm{ST}_{\mathrm{a}}$ binding capacity of 3 wk-old unweaned pigs $\left(17.48 \pm 2.10\right.$ versus $4.86 \pm 1.02 \times 10^{-11}$ $\mathrm{mol} / \mathrm{L}, p<0.001)$. After weaning, the $\mathrm{ST}_{a}$ binding capacity decreased by $6 \mathrm{wk}$ to levels similar to that seen in the adult animals $\left(8.60 \pm 0.60\right.$ versus $6.00 \pm 0.96 \times 10^{-11} \mathrm{~mol} / \mathrm{L}, p=$ NS). Changes in $\mathrm{ST}_{\mathrm{a}}$ binding activity did not correlate with changes in sucrase activity. As also shown in Figure 2, sucrase activity increased from the $1 \mathrm{st}$ wk of life until the time of weaning ( 3 wk unweaned). Sucrase activity then decreased to adult levels

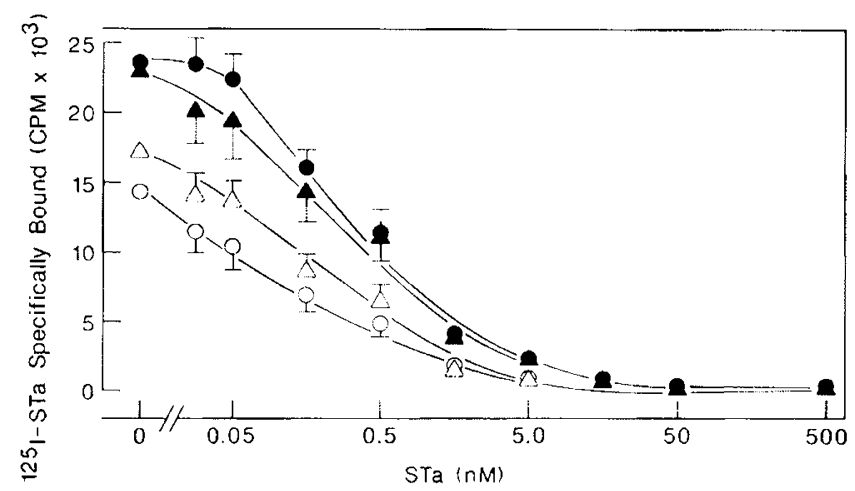

Fig. 1. Competitive inhibition of ${ }^{125} \mathrm{I}_{-} \mathrm{ST}_{\mathrm{a}}$ binding to jejunal BBM by increasing doses of native $\mathrm{ST}_{\mathrm{a}}$. Jejunal BBM from immature ( $\leq 1$-wkold) $(\bullet)$, adult $(O)$, 3-wk-old weaned $3 \mathrm{~d}$ before sacrifice $(\boldsymbol{\Lambda})$, and 3-wkold unweaned $(\triangle)$ pigs were incubated for $60 \mathrm{~min}$ in $1 \mathrm{~mL}$ of $100 \mathrm{mM}$ sodium acetate buffer $(\mathrm{pH} 4.8)$ at $37^{\circ} \mathrm{C}$ with $100000 \mathrm{cpm}$ of ${ }^{125} \mathrm{I}-\mathrm{ST}$ : Binding of ${ }^{125} \mathrm{I}_{-} \mathrm{ST}:$ was determined as described in Materials and Methods. Results are mean \pm SEM of three to eight separate determinations. 

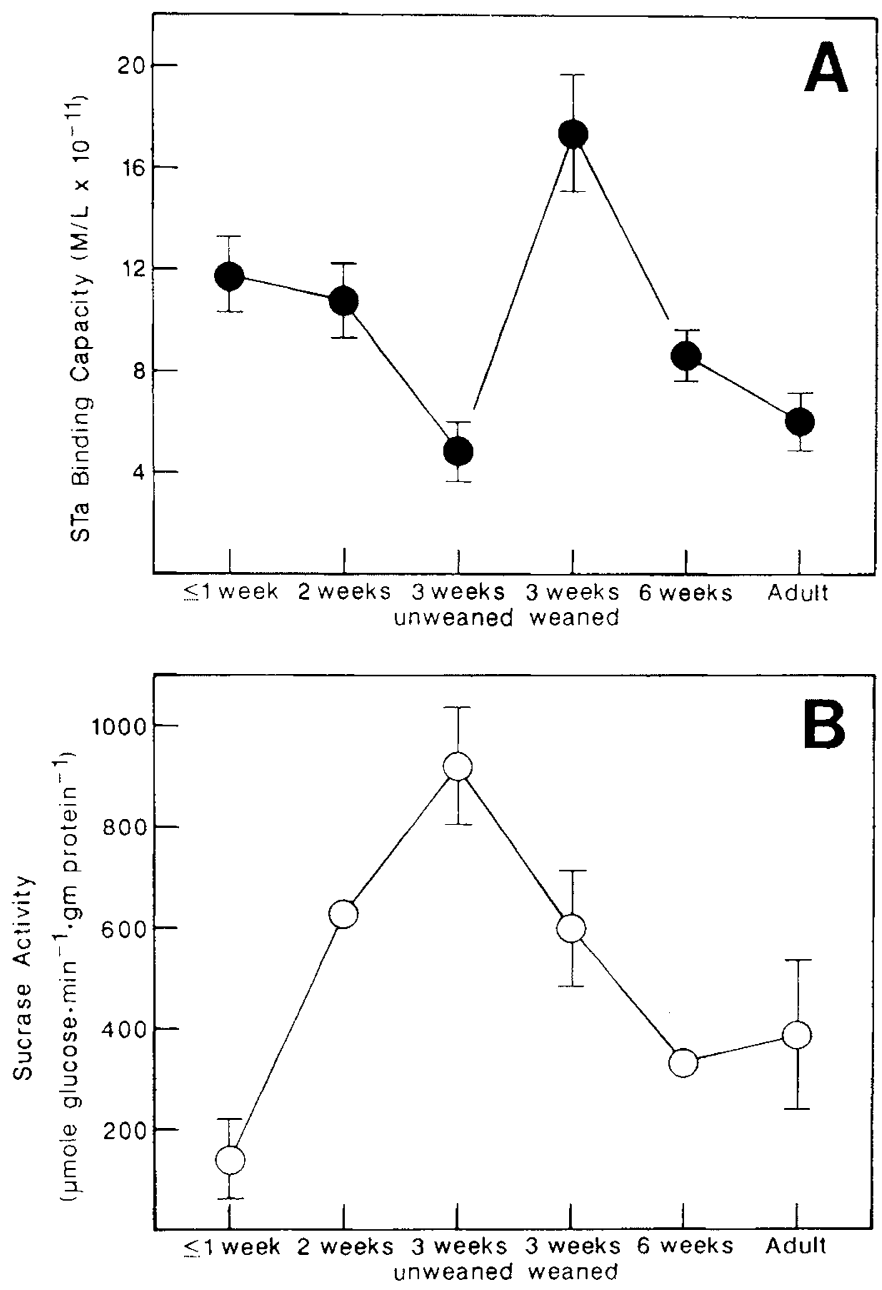

Fig. 2. $\mathrm{ST}_{\mathrm{a}}$ binding capacity $(A)$ and sucrase activity $(B)$ in BBM prepared from pigs of various ages. $\mathrm{ST}_{\mathrm{a}}$ binding activity was calculated by Scatchard analysis of competitive inhibition of binding experiments (see Fig. 1) using the computer program Ligand (19). Sucrase activity was measured as described in Materials and Methods. Results are mean \pm SEM of three to eight separate determinations, except for sucrase activity at $14 \mathrm{~d}$ and $6 \mathrm{wk}$, where results are the mean of two determinations.

at the time of weaning ( $3 \mathrm{wk}$ weaned), a time when $\mathrm{ST}_{\mathrm{a}}$ binding activity was highest.

Guanylate cyclase activation. $\mathrm{ST}_{\mathrm{a}}$ stimulated $\mathrm{BBM}$ guanylate cyclase activation in a dose-dependent manner in all specimens tested. Guanylate cyclase stimulation increased linearly with increasing concentrations of BBM protein added, between 2.5 and $20 \mu \mathrm{g}$. Increasing guanylate cyclase activation was also directly related to increasing incubation time between 1 and 10 min, at which point a plateau was reached. Therefore, all experiments were performed with an incubation time of $3 \mathrm{~min}$, at $32^{\circ} \mathrm{C}$, with $10 \mu \mathrm{g}$ of $\mathrm{BBM}$ protein added. The dose-response curves generated by these experiments are shown in Figure 3. Sensitivity to $\mathrm{ST}_{\mathrm{a}}$ stimulation was similar at all ages tested, with a concentration of $\mathrm{ST}_{\mathrm{a}}$ of approximately $36 \mathrm{nM}$ required to generate a half maximal response. Maximum guanylate cyclase stimulation varied greatly from animal to animal within each age group; however, the average maximal response in immature pigs was 4 -fold greater than the average maximal response in adult animals $(1312 \pm 831$ versus $320 \pm 92 \mathrm{pmol} / \mathrm{mg}$ BBM protein $/ \mathrm{min}, p<0.02$ ). The average maximal stimulation of guanylate cyclase was greater in 3-wk-old weaned pigs than in 3wk-old suckling pigs $(1126 \pm 692$ versus $624 \pm 298 \mathrm{pmol} / \mathrm{mg}$ $\mathrm{BBM}$ protein/min); however, this difference did not achieve statistical significance because of interanimal variability.

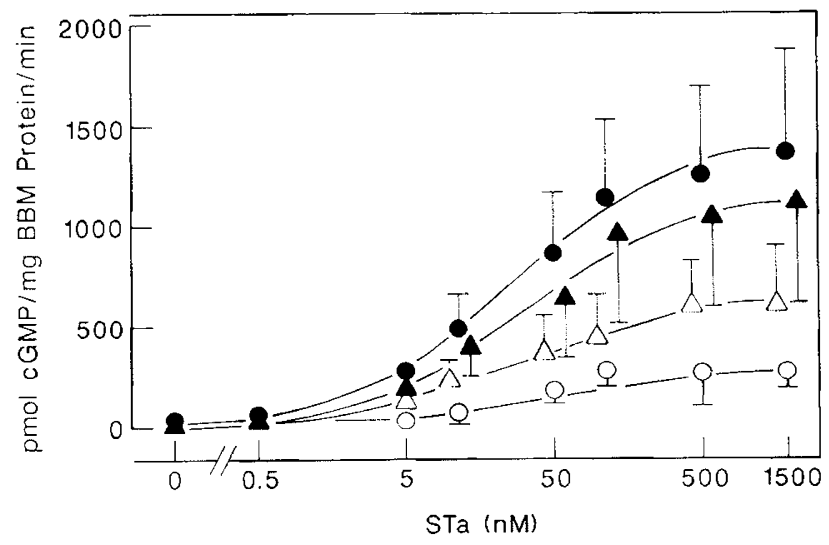

Fig. 3. Effect of increasing concentrations of $\mathrm{ST}_{\mathrm{a}}$ on guanylate cyclase activation in membranes prepared from immature ( $\leq 1$-wk-old) $(\bullet)$, adult $(\mathrm{O})$, 3-wk-old weaned $3 \mathrm{~d}$ before sacrifice $(\boldsymbol{\Lambda})$, and 3-wk-old unweaned $(\triangle)$ pigs as described in Materials and Methods. Sensitivity to $\mathrm{ST}_{2}$ stimulation was similar at all ages tested, with $\mathrm{ED}_{50}$ at approximately 36 $\mathrm{nM}$ of $\mathrm{ST}_{\mathrm{a}}$ added, for all pigs.

Photoaffinity cross-linking. Two separate BBM preparations from pigs at ages $1 \mathrm{~d}, 5 \mathrm{~d}, 7 \mathrm{~d}, 14 \mathrm{~d}, 6 \mathrm{wk}$, and adult, as well as three separate BBM preparations from 3-wk-old weaned and 3wk-old unweaned pigs, were subjected to photoaffinity crosslinking, SDS-PAGE, and autoradiography. As shown in Figure 4 , a number of distinct, specifically radiolabeled bands are apparent on these autoradiograms. In the adult, there is a prominent band at approximately $66 \mathrm{kD}$, whereas in the immature $(5-$ d-old) pig there are bands of similar intensity at approximately 62,84 , and $160 \mathrm{kD}$ (Fig. 4A). This pattern also occurred in other pigs $<3 \mathrm{wk}$ old (data not shown). Nonspecific cross-linking to a $43-\mathrm{kD}$ band also occurred at all ages. At $3 \mathrm{wk}$ of age, both the immature and adult patterns were present (Fig. $4 B$ ). The immature pattern was present in two out of three weaned pigs tested, and the adult pattern was present in two of the three unweaned pigs evaluated. There were also small but consistent differences in the apparent molecular weight of the proteins to which $\mathrm{ST}_{\mathrm{a}}$ was cross-linked in different age animals (Figs. 4 and $5)$. As shown in Figure $4 B$, radiolabeled bands are seen at approximately $62 \mathrm{kD}$ in the unweaned pig and at approximately 66,92 , and $165 \mathrm{kD}$ in the weaned pig. These differences were confirmed in separate experiments in which the $62-$ to $66-\mathrm{kD}$ bands from adult and 1-d-old animals did not comigrate in a single lane of a SDS-PAGE (data not shown).

To further evaluate whether these autoradiographic bands represented larger protein complexes, we subjected the BBM to $0.01 \%$ trypsin for $10 \mathrm{~min}$ at room temperature, followed by photoaffinity cross-linking with ${ }^{125}{ }^{25}-S_{a}$. As shown in Figure 5 , trypsin treatment had virtually no effect on adult BBM. A prominent $66-\mathrm{kD}$ band is apparent on both trypsin-treated and untreated lanes. However, at all other ages, there was a trypsin effect. In the 1-d-old pig, the untreated lane has specifically radiolabeled bands at approximately 160 and $84 \mathrm{kD}$. After treatment with trypsin, there is a decreased intensity of the 84$\mathrm{kD}$ band and appearance of a prominent $62-\mathrm{kD}$ band. In the 3wk-old weaned pig, the untreated lane has specifically radiolabeled bands of similar intensity at approximately 165, 92, and $66 \mathrm{kD}$. After treatment with trypsin, there is decreased intensity of the $165-\mathrm{kD}$ band and more prominent labeling of the $92-$ and $66-\mathrm{kD}$ bands. A similar pattern with slightly different molecular weight bands is seen after trypsin treatment of the 3-wk-old unweaned pig; in this lane, there is more prominent radiolabeling of bands at 84 and $62 \mathrm{kD}$.

\section{DISCUSSION}

We have shown that $\mathrm{ST}_{\mathrm{a}}$ binds to porcine jejunal $\mathrm{BBM}$ and activates guanylate cyclase in both immature and adult pigs. Our 

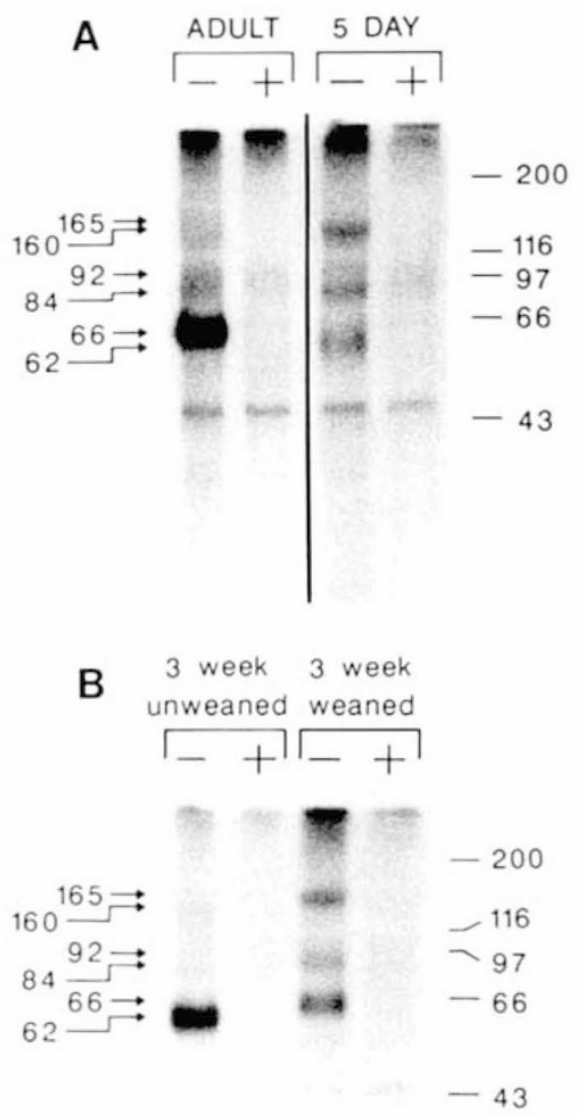

Fig. 4. Representative autoradiograms of SDS-PAGE with ${ }^{125}$ I-ST cross-linked to porcine jejunal BBM of various age pigs. Cross-linking with $\mathrm{N}$-hydroxysuccinimidyl-4-azidobenzoate was performed after incubation of ${ }^{125} \mathrm{I}_{-} \mathrm{ST}_{\mathrm{a}}$ in the presence (+) and absence (-) of excess native $\mathrm{ST}_{\text {ia }}$, as described in Materials and Methods. $A$, adult and 5-d-old pigs. $B$, weaned and unweaned pigs, age $3 \mathrm{wk}$.

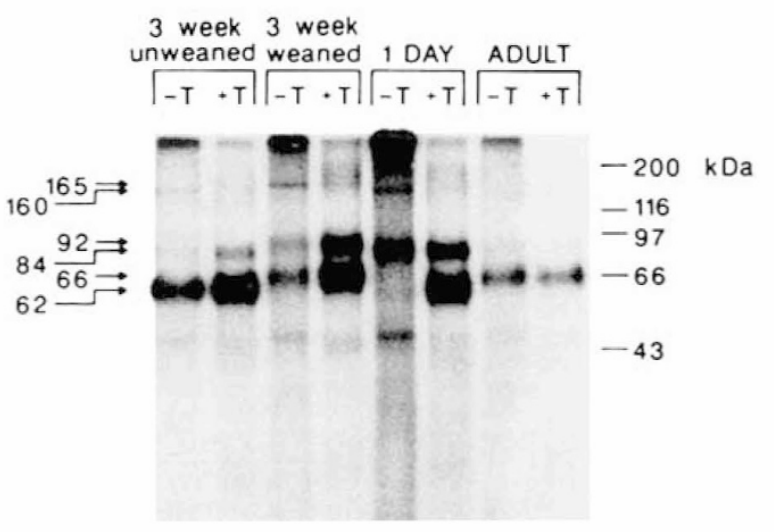

Fig. 5. Representative autoradiogram of SDS-PAGE with ${ }^{125} \mathrm{I}_{-} \mathrm{ST}_{2}$ cross-linked to porcine jejunal BBM of various age pigs after treatment with trypsin $(+T)$ or trypsin-free buffer $(-T)$. Cross-linking of ${ }^{125} \mathrm{I}-\mathrm{ST}_{\text {: }}$ to BBM with $\mathrm{N}$-hydroxysuccinimidyl-4-azidobenzoate is shown only in the absence of excess native $\mathrm{ST}_{\mathrm{a}}$ (see Fig. 4).

data demonstrate that $\mathrm{ST}_{\mathrm{a}}$ binding capacity is nearly 2-fold greater, and $\mathrm{ST}_{\mathrm{a}}$-induced guanylate cyclase activation is nearly 4-fold greater in the jejunal BBM specimens obtained from immature pigs. These differences parallel changes that have been observed in rats and humans $(5,6,22)$, and may increase the susceptibility of immature pigs to $\mathrm{ST}_{\mathrm{a}}$-mediated diarrheal disease. Weaned pigs demonstrated more than a 3 -fold greater binding capacity for $\mathrm{ST}_{\mathrm{a}}$ than their unweaned 3-wk-old counterparts. Maximum guanylate cyclase activation in weaned pigs was nearly 2 -fold greater than the average maximal stimulation seen in suckling pigs, although this difference did not achieve statistical significance due to significant interanimal variability. It is possible that confounding variables, such as stress, may alter the response to $\mathrm{ST}_{\mathrm{a}}$ in weaned pigs. The stress associated with forced separation of immature animals from their dams at weaning may induce hormonally mediated changes in BBM (23). Stress might similarly affect the $\mathrm{ST}_{\mathrm{a}}$-mediated responsiveness of guanylate cyclase.

Other factors may also be involved in the increased sensitivity of weaning pigs to $\mathrm{ST}_{\mathrm{a}}$-mediated diarrheal disease. The data of Miller et al. (24) and of Hall and Byrne (25) suggest that weaning diarrhea is due to host factors that induce a cell-mediated immune response to dietary antigens and result in damage to the small intestinal mucosa at the time of introduction of a pelleted meal. Sarmiento et al. (26) suggest that the change in dietary antigens at weaning may not be required for the induction of diarrhea, but may modestly increase its severity. However, Hampson (27) found that the changes occurring in the intestinal mucosa at weaning may be present in the absence of diarrhea, and therefore postulates that dietary antigens play little role in weaning diarrhea. Lönnroth et al. (28) have identified an antisecretory factor in sow's milk that is protective against infection with $\mathrm{ST}_{2}$-producing $E$. coli, as long as the animal is still suckling. Weaning deprives animals of this factor, and they therefore have an increased incidence of $\mathrm{ST}_{\mathrm{a}}$-mediated diarrhea.

Although it is likely that there are multiple factors contributing to the increased susceptibility of pigs to enterotoxigenic $E$. coli at weaning, and no one factor will explain this predilection, our data suggest a unifying concept. The variable guanylate cyclase response to $\mathrm{ST}_{\mathrm{a}}$ that we observed may signify a predisposition to increased secretion in a selected population of pigs (hypersecretors). This predisposition might be variably expressed on the basis of permissive host factors, including BBM changes induced by dietary antigens $(24,25)$, or by environmental factors, including decreased maternal antisecretory factor (28) or stress. The hypersecretors, when exposed to $\mathrm{ST}_{\mathrm{a}}$, have increased guanylate cyclase activation and intestinal fluid secretion, and therefore an increase in sensitivity to $\mathrm{ST}_{\mathrm{a}}$-mediated diarrheal disease. This increased susceptibility might be augmented or more fully expressed by the action of any of these host or environmental factors.

Autoradiograms of BBM that were photoaffinity-labeled with ${ }^{125} \mathrm{I}_{-} \mathrm{ST}_{\mathrm{a}}$ and separated by SDS-PAGE show different patterns with age. In the adult, there is a prominent band at approximately $66 \mathrm{kD}$. In contrast, in the immature pig there are several radiolabeled bands. In the 1-d-old pig there is no band corresponding to the $66-\mathrm{kD}$ band seen in the adult. However, after treatment with trypsin, there is appearance of a new $62-\mathrm{kD}$, but not a $66-$ $\mathrm{kD}$, radiolabeled band. A $160-\mathrm{kD}$ band is seen in the 1-d-old and 3-wk-old unweaned pigs, whereas a slightly larger, 165-kD band is seen in the weaned pigs. However, after treatment with trypsin, the intensity of all of these bands diminishes and there is increased or new radiolabeling of smaller bands $(62 \mathrm{kD}$ in the $1-\mathrm{d}$ old, 62 and $84 \mathrm{kD}$ in the unweaned, and 66 and $92 \mathrm{kD}$ in the weaned). The higher ( 84 to 92 and 160 to $165-\mathrm{kD}$ ) bands were most prominent in immature pigs and $62-$ to $66-\mathrm{kD}$ bands were most prominent in older pigs. Thus, there appears to be a difference in the size of the radiolabeled bands, the relative proportion of certain size classes of radiolabeled bands, and the degree of trypsin sensitivity of these bands in various age pigs. On the basis of these data, we suggest that there are structural changes with age and weaning at the $\mathrm{ST}_{\mathrm{a}}$ binding site. It is possible that the two smaller molecular weight species are subunits of the larger $160-$ to $165-\mathrm{kD}$ complex. Within a given size 
class of proteins to which $\mathrm{ST}_{\mathrm{a}}$ was specifically cross-linked, e.g. 62-66 kD, there were small but reproducible differences in apparent molecular weight as a function of age and weaning. These differences in apparent molecular weight may represent changes in glycosylation of these proteins.

In summary, we have demonstrated an increased binding capacity and guanylate cyclase activation of proximal jejunal segments of immature versus mature pigs, and an increased binding capacity of weaned versus suckling pigs. We have also shown a difference in the autoradiograms obtained from ${ }^{125}{ }^{1-S T} T_{a}$ photoaffinity-labeled BBM from these animals, implying structural changes in the BBM receptor with age. These results may help explain the increased susceptibility of immature and weaned animals to $\mathrm{ST}_{\mathrm{a}}$-mediated diarrheal disease. This model can be used for future studies addressing the regulation of factors that cause increased host responsiveness or increased susceptibility to diarrhea caused by enterotoxigenic $E$. coli.

Acknowledgments. The authors thank Dr. H. Moon for helpful discussion and for assistance in obtaining tissues, S. M. Skartvedt for technical assistance, and Drs. William F. Balistreri and Ralph A. Giannella for their critical review of this manuscript.

\section{REFERENCES}

1. Giannella RA, Luttrell M, Thompson M 1983 Binding of Escherichia coli heat-stable enterotoxin to receptors on rat intestinal cells. Am J Physiol 245:G492-G498

2. Fieid M, Graf LH, Laird WJ, Smith PL 1978 Heat stable enterotoxin of Escherichia coli: in vitro effects on guanylate cyclase activity, cyclic GMP concentration, and ion transport in small intestine. Proc Natl Acad Sci USA 75:2800-2804

3. Guerrant RL, Hughes JM, Chang B, Robertson DC, Murad F 1980 Activation of intestinal guanylate cyclase by heat stable enterotoxin of Escherichia coli studies of tissue specificity, potential receptors, and intermediates. J Infect Dis 142:220-228

4. Giannella RA, Drake KW 1979 Effect of purified $E$. coli heat stable enterotoxin on intestinal cyclic nucleotide metabolism and fluid secretion. Infect Immun 24:19-23

5. Cohen MB, Guarino A, Shukla R, Giannella RA 1988 Age-related differences in receptors for Escherichia coli heat-stable enterotoxin in the small and large intestine of children. Gastroenterology 94:367-373

6. Cohen MB, Moyer MS, Luttrell M, Giannella RA 1986 The immature rat small intestine exhibits an increased sensitivity and response to Escherichia coli heat stable enterotoxin. Pediatr Res 20:555-560

7. Black RE, Merson MH, Rahman AS, Yunus M, Alim AR, Huq I, Yolken RH, Curlin GT 1980 A two year study of bacterial, viral, and parasitic agents associated with diarrhea in rural Bangladesh. J Infect Dis 142:660-664
8. Black RE, Brown KH, Becker S, Yunus M 1982 Longitudinal studies of infectious diseases and physical growth in rural Bangladesh: I. Patterns of morbidity. Am J Epidemiol 115:305-314

9. Whipp SC, Moon HW, Argenzio RA 1981 Comparison of enterotoxigenic activities of heat-stable enterotoxins from class 1 and class 2 Escherichia coli of swine origin. Infect Immun 31:245-251

10. Biehl LG, Hoefling DC 1986 Diagnosis, treatment, and prevention of diarrhea in 7- to 14-day-old pigs. J Am Vet Med Assoc 188:1144-1146

11. Stevens JB, Gyles GL, Barnum DA 1971 Production of diarrhea in pigs in response to Escherichia coli enterotoxin. Am J Vet Res 33:2511-2526

12. Sarmiento JI, Casey TA, Moon HW 1988 Postweaning diarrhea in swine: experimental model of enterotoxigenic Escherichia coll infection. Am J Vet Res 49:1154-1159

13. Staples JS, Asher SE, Giannella RA 1980 Purification and characterization of heat-stable enterotoxin produced by a strain of $E$. coli pathogenic for man. J Biol Chem 255:4716-4721

14. Thompson MR, Luttrell M, Overmann G, Giannella RA 1985 Biological and immunological characteristics of ${ }^{125} \mathrm{I}-E$. col $i$ heat-stable enterotoxin species purified by HPLC. Anal Biochem 148:26-36

15. Lowry OH, Rosebrough H, Farr AL, Randall RJ 1951 Protein measurement with the Folin phenol reagent. J Biol Chem 193:265-275

16. Schmitz J, Preiser H, Maestracci D, Ghosh BK, Cerda JJ, Crane RK 1973 Purification of human intestinal brush border membrane. Biochem Biophys Acta 323:98-112

17. Dahlqvist A 1968 Assay of intestinal disaccharidases. Anal Biochem 22:99107

18. Koldovsky O, Asp NG, Dahlquist A 1969 A method for the separate assay of "neutral" and "acid" beta-galactosidase in homogenates of rat small intestinal mucosa. Anal Biochem 27:409-418

19. Munson PJ, Rodbard D 1980 LIGAND: a versatile computerized approach for characterization of ligand-binding systems. Anal Biochem 107:220-239

20. Waldman SA, O'Hanley PD, Falkow S, Schoolnik G, Murad F 1984 A simple, sensitive and specific assay for the heat-stable enterotoxin of Escherichia coli. J Infect Dis 149:83-89

21. Laemmli UK 1970 Cleavage of structural proteins during the assembly of the head of bacteriophage $T_{4}$. Nature 227:680-685

22. Guarino A, Cohen MB, Giannella RA 1987 Small and large intestinal guanylate cyclase activity in children: effect of age and stimulation by Escherichia coli heat-stable enterotoxin. Pediatr Res 21:551-555

23. Henning SJ 1986 Development of the gastrointestinal tract. Proc Nutr Soc 45:39-41

24. Miller BG, Newby TJ, Stokes CR, Bourne FJ 1984 Influence of diet on postweaning malabsorption and diarrhea. Res Vet Sci 36:187-193

25. Hall GA, Byrne TF 1989 Effects of age and diet on small intestinal structure and function in gnotobiotic piglets. Res Vet Sci 47:387-392

26. Sarmiento JI, Dean EA, Moon HW 1988 Effects of weaning on diarrhea caused by enterotoxigenic Escherichia coli in three-week-old pigs. Am J Vet Res 49:2030-2033

27. Hampson DJ 1986 Alterations in piglet small intestine structure at weaning Res Vet Sci 40:32-40

28. Lönnroth I, Martinsson K, Lange S 1988 Evidence of protection against diarrhea in suckling piglets by a hormone-like protein in the sow's milk. J Vet Med B35:628-635 